light reflected from the film is passed through a lens, and an image formed upon a screen. When the bands of colour are seen descending from the upper part of the film, a current from fifty Grove's cells is passed through it. If the current flows downwards the bands of colour move more quickly than before; if it flows upwards their motion is checked and they begin to ascend. The cause of this curious fact is still unknown. It may either be analogous to the phenomenon known as the. "migration of the ions," or it may be a secondary effect due to a change in the surface tension.

The general relation of the results attained by these investigations as to the question of the size of molecules is interesting. Sir William Thomson has expressed the opinion that $2 \times 10^{-6}$ $\mathrm{mm}$. and $0^{\circ}$ or $\times 10^{-6} \mathrm{~mm}$. are superior and inferior limits respectively to the diameter of a molecule. Van der Waals has been led, from considerations founded on the theory of gases, to give $0.28 \times 10^{-6} \mathrm{~mm}$. as an approximate value of the diameters of the molecules of the gases of which the atmosphere is composed. The number of molecules which could be placed side by side within the thickness of the thinnest soap film would, according to these various estimates, be 4,26 , and 720 respectively. The smallness of the nirst of these numbers, especially when it is remembered that the liquid tised on some occasions was of a highly complex character, containing water, glycerine, and soap, points to the conclusion that the diameter of a molecule is considerably less than $2 \times 10^{-\beta} \mathrm{mm}$.

\section{THE FAUNA OF THE SEASHORE}

THE marine fauna of the globe may be divided into the littoral, the deep-sea, and the pelagic faunas. Of the three regions inhabited by these faunas, the littoral is the onc in which the conditions are most favourable for the development of new forms through the working of the principle of natural selection. As Prof. Lovén writes, "The littoral region comprises the favoured zones of the sea where light and shade, a genial temperature, currents changeable in power and direction, a rich vegetation spread over extensive areas, abundance of food, of prey to allure, of enemies to withstand or evade, represent an infinitude of agents competent to call into play the tendencies to vary which are embodied in cach species, and always ready by modifying its parts to respond to the influences of external conditions." It is consequently in this littoral zone where the water is more than elsewhere favourable for respiration, and where constant variation of conditions is produced by the tides, that all the main groups of the animal kingdom first came into existence; and here also, probably, where the first attachod and branching plants were developed, thus establishing a supply of food for the colonisation of the region by animals.

The animals inhabiting the littoral zone are most variously modified, to enable them to withstand the peculiar physical conditions which they encounter there. Hence the origin of all hard shells and skeletons of marine invertebrata, various adaptations for boring in sand, the adoption of the stationary fixed condition, and similar arrangements. Almost all the shore forms of animals, however inert in the adult condition, pass through in embryological development frec-swimming larval stages which are closely alike in form for very widely different groups of animals. Thus the oyster and most other mollusca of all varieties ${ }^{7}$ and shapes when adult develop from a free-swimming pelagic trochosphere larva, and so do many annelids. Such larva cannot be of subsequent origin to the adults of which they are phases. If such were the case, they would not have become so closely alike in structure. In reality they represent the common ancestors from which all the forms in which they occur were derived, and as all these larve are pelagic in habits and structure, it follows that the inhabitants of the shores were derived from pelagic ancestors. The earliest plants were also probably free-swimming.

In the case of the cirripedia there can be no doubt, from the history of their development, that they were originally pelagic, and have become specially modified for coast life; and in the case of the echinoderms the only possible explanation of the remarkable similarity of the larval forms of the various groups of widely differing adults is that these pelagic larvæ represent a common ancestor of the group. The madreporarian corals all spring from a pelagic larvo. The colonial forms probably owe their origin and that of their skeletons to the advantage gained 1 Abstract of lecture at the Royal Institution by Prof. H. N. Moseley,
M.A., F.R.S. by them in the formation of reefs, and the increase in facilities of respiration consequent on the production of surf. In the deep sea they are very scarce.

The vertebrata are sprung from a very simple free-swimming ancestor, as shown by the ciliated gastrula stage of Amphioxus. The ascidians afford another evident instance of the extreme modification of pelagic forms for littoral existence.

The peculiar mode of respiration of vertebrata by means of gill-slits occurs in no other animal group except in Balanoglossus, which will probably shortly be included amongst vertebrata. Possibly gill-slits as a respiratory apparatus first arose in a littoral form, such as Balanoglossus, and hence their presence at the anterior end of the body, that nearest to the surface in an animal buried in sand. The connection of Balanoglossus with the echinoderms through Tornaria is very remarkable. Possibly Amphioxus once had a Tornaria stage, and has lost it just as one species of Balanoglossus has lost it, as Mr. Bateson has lately discovered.

The littoral zone has given off colonists to the other three faunal regions. The entire terrestrial fauna has sprung from colonists contributed by the littoral zone. Every terrestrial vertebrate bears in its early stages the gill-slits of its aquatic ancestor. All organs of aërial respiration are mere modifications of apparatus previously connected with aquatic respiration, excepting, perhaps, in the case of Tracheata, tracheæ being most likely modifications of skin-glands, as appears probable from their condition in Peripatus. The oldest known air-breathing animals are insects and scorpions, which have lately been found in Silurian strata. Prof. Ray Lankester believes the lungs of scorpions to be homogeneous with the gill-plates of Limulus. Birds were possibly oriqinally developed in connection with the seashore, and were fish-eaters like the tooth-bearing Hesperornis.

The fauna of the coast has not only given rise to the terrestrial and fresh-water fauna; it has from time to time given additions to the pelagic fauna in return for having thence derived its own starting-points. It has also received some of these pelagic forms back again, to assume a fresh littoral existence.

The deep-sea fauna has probably been formed almost entirely from the littoral, not in the remotest antiquity, but only after food derived from the debris of the littoral and terrestrial-faunas and floras became abundant.

It is because all terrestrial and deep-sea animal forms have pasced through a littoral phase of existence, and that the littoral animals retain far better than those of any other faunal region the recapitulative larval phases by means of which alone the true histories of their origins can be recovered, that marine zoolog'cal laboratories on the coast have made so many brilliant discoveries in zoology during late years.

The lecturer concluded by appealing for as istance, in the way of subscriptions, to the funds of the Marine Biological Association of Great Britain, the object of which is to construct a marine laboratory on the English coast for the purpose of researches such as those referred to. England is at present without any such laboratory, although nearly all Continental countries possess them.

\section{THE PHILOSOPHICAL SOCIETY OF GLASGOW}

THE Proceedings of this Society for $1884-85$ have just been issued in a volume of 408 pages, with six plates and two maps. The following are the principal contributions:-On feeling and perception of relation, by Dr. H. Muirhead, President; on the proper motions of the stars, by Prof. Grant on the first editions of the chemical writings of Democritus and Synesius, by Prof. Ferguson; on the composition of ocean water, by Prof. Dittmar; on the regulation of the supply of water to cities and towns, by Mr. W. Key; on a shadowless gas ventilator, by Mr. George A. Buchanan; on African colonies and colonisation, by J. E. Carlyle; a memoir of the late Mr. James Napier: on a new musical instrument, by Mr. Thomas Machell ; on a description of a new Rotiferon, by Mr. W. Milne; on a theory of storm-travel, by Mr. P. Alexander; on national and local precautions against cholera, by Dr. James Christie; on an air or gas thermometer, by Mr. J. J. Coleman; on some experiments on the influence of cold on the putrefactive process, by Mr. J. J. Coleman and Prof. McKendrick; on the liquefaction of air and other effects of extreme cold, and on artificial light and other phenomena of high temperature, by Mr. J. J. 
Coleman; on sanitary arrangements and house-building in towns, by Mr. James Sellars; on Egyptian obelisks, by Mr. T. L. Patterson; on producing cast iron or ingot iron from crude or pig iron, by Mr. W. Gorman; on the heat-restoring gas furnace and heating by radiation, by Mr. W. Gorman; on uncertified deaths, by Dr. Glaister; on the spread of disease by manure poisoning, by Dr. E. Duncan ; and on the form of the human skull, by Prof. Cleland. The two maps, prepared by Mr. Ravenstein, and presented to the Society by Mr. James Stevenson, are specially valuable as showing the most recent results of African travel.

During the session M. Louis Pasteur, Prof. $\Lambda$ sa Gray, and Rev. John Kerr, LL.D., were elected honorary members, and Mr. George Anderson, lately M.P. for Glasgow, and now Master of the Mint, Melbourne, was elected a corresponding member The Graham medal was awarded to Mr. E. C. C. Stanford for his researches on algin. The Society at present has I8 honorary, II corresponding, and 69I ordinary members, and in addition to the ordinary meetings, there are sections for architecture, chemistry, biology, sanitation and social economy, and geography and ethnology.

\section{AN EARTHQUAKE INVENTION}

$W^{E}$ have been requested to publish the following correspondence :-

Royal Observatory, Edinburgh, Fune 5, 1885

My Dear Mr. David Stevenson,-At p. 248 of the new British Association volume for 1884 there is a section on "Experiments on a Building to Resist Earthquake Motion," which reads amazingly like your paper of twenty years ago; but yet it is not that, for your name does not enter, and they have in a way got round the letter of your invention by employing, in place of your bronze balls in shallow bronze basins, cast iron balls and cast-iron plates, "with saucer-like edges" for the lower basins; and for the upper basins, "cast iron plates slightly concave, but otherwise similar to those below."

Against such men would any patent be safe? though you may not have taken out any patent for your philanthropic invention for saving life in earthquake-persecuted countries; but the whole section is the most indubitable approval of your methods and principles that could well have been proposed by any one. Certainly it transcends anything that could have ever entered the mind of Yours ever very sincerely,

\section{Prazzi Smyth}

Edinburgh, Fune II, 1885

DEAR SIR,--Very many thanks for your letter to my father pointing out the report of the British Association on earthquakes for 1884 , which I had not seen. My father, from the state of his health, is unfortunately unable to take the matter up himself, but if you will permit me to publish your very interesting and well-put letter in NATURE it will give the honour of the invention to whom the honour is due. My father, who read your letter with great interest, begged to be remembered to "his old friend." In order to save you the trouble of writing again I shall assume, if I do not hear from you in a few days, that you have no objection to your letter being published.

I may mention that the balls for the Japanese aseismatic arrangements for the towers were made of cast iron, and those for the tables in the light-rooms were of gun-metal.

$$
\text { Yours very truly, }
$$

Professor Piazzi Smyth, \&c., \&c.

\section{A. Stevenson}

\section{Westford House, Droitwich, Fune 13, $188_{5}$}

Dear Mr. D. A. Stevenson,-Yours of the IIth has reached me here ; and, as I left Edinburgh on that day, it was a happy thought of yours to say that, if you did not hear from me soon you would assume my consent to your making some public use of my letter to your worthy father. For, in so far as I wrote it at all, I am ready to stand by it before many or few.

But it was only the beginning of what might have been said and that I trust you will have perceived, and will supply some of the remaining notanda, such as the B.A. man praising up the system for so decidedly relieving the ball-supported build ing from all the sharp, destructive effects of an earthquakeshock, and leaving only a gentle to-and-fro motion on the balls -because this was so admirably illustrated on your father's experimental model at Milton House-by the ease and safety with which the model lighthouse standing on balls in basins was knocked all about the yard by men with sledge-hammers, when they struck only the lower basins, or what they were fixed on as representing solid, yet earthquake-affected, ground; but the moment they struck the base of the lighthouse taken off the basins and balls and planted on the ground, down toppled lantern and lamps with such a fracture, that no more experiments could be made that day.

Then, again, your father had duly allowed that his system would not defend from vertical earthquake-shocks, but he hoped that they would be far more rare at any one place than horizontal shocks spreading all around and far from the places of vertical action; and exactly so says the B.A. man for himself and his imitation balls and basins.

And then he concludes with that he does hope for so much alleviation to human suffering in earthquake regions from the large amount of safety that balls and basin supports for dwellings must give in a gereral way that seismic science will be elevated in the eyes of the people, or something to that effect. To all which of course you can perfectly agree, both in your own and your father's name. I can mention that the turning-point with him as to the practicability of the scheme was when he ascertained by rigid and calm scientific measures that the amount of absolute motion which had done the most mischief in some of the worst Italian earthquakes was not more than three inches, so that it came legitimately within the compass of the means he first suggested, and R.S.S. Arts duly stamped with its approval ten years ago.

Hereabouts is a different earth effect-viz. the High Street, so called, of Droitwich-going down slowly but surely to fill up the vacancies occasioned below by the ceaseless bringing up of salt-rock dissolved in water pumped by numberless steamengines, and furnishing, it is said, half the human family with that one necessary mineral condiment, salt; and so much vapour of it is in the air that mere residence here for a time is said to cure rheumatism and other complaints, even without taking the celebrated brine baths, of ten times the saltness of the ocean itself. Yours very truly,

\section{PIAZZI SMY'TH}

P.S. - The spectroscopic salt line D is preternaturally strong in the air here; "D" might stand for Droitwich.

\section{SCIENTIFIC SERIALS}

Fournal of the Russian Chemical and Physical Society, vol. xvii. fasc. I. - Annual reports of the Society. - On the isomerism of hydrocarbons according to the theory of substitution, by M. Menshutkin (analysed in another column).-On the preparation of hemines, by M. Schalfeyeff.-On its crystalline forms, by A. Lagorion (with plates). - Notes on an apparatus for washing precipitates; on the oxidation of aromatic amines ; on the action of alcohol on diazo compounds. - On the isomerism of solutions, by W. Alexeyeff.-On the same, by D. Konovaloff.-Minutes of proceedings of the physico-chemical section of the Moscow Socicty of amateurs of Natural Sciences.-On the electrolytic figures of Nobili and Gebhard in the magnetic field, by W. Stchegliaeff (with a plate). - On the collision of absolutely rigid bodies, by $\mathrm{N}$. Schiller, being a mathematical inquiry, to show that the invariability of the vis viziz can be establisher by the geometrical determination of the absolute invariability of the systems.-On the dilatation of liquids, by $\mathrm{K}$. Jouk. Researches at the University of Kieff proved that common ether, ethylic alcohol, sulphurous anhydride, diethylamine, and chloric ethyl comply with the formula $v=a+b \log (\tau-t)$.-Polemic between MM. Kraewitsch, Stoletoff, and Petroff.

Vol. xvii., fasc. 2. - Thermal data for hydrocarbon compound o bromide of aluminium, by G. Gustavson. The figures foind by Berthelot, give for the molecule $\mathrm{Al}_{2} \mathrm{Br}_{6}$ a heat of dissolution equal to 170,600 units, M. Gustavson has found, from a series of six determinations, an average of 180,237 (from 179,926 to $\left.180,76_{3}\right)$. When taking $\mathrm{AlBr}_{3} 3\left(\mathrm{C}_{7} \mathrm{H}_{8}\right)$, the number of calorics received was nearly 168 (from 168 , 00I to 168,567 ). On diallyloxalic acid, and on the preparation of oxalic ether, by E. Schatzky.-On the formation of carbonates of strontium, barium, and calcium, by J. Bevad, being an inquiry into the rapidity of reactions. - On the change of colours of coloured surfaces under artificial light, by Th. Petrushevsky. 